\title{
Influence of degradation processes upon normative money evaluation of plouhglands
}

\author{
O. Hodakivska, \\ candidate of economic sciences \\ N. Solovianenko, A. Matviyenko \\ National Science Center "Institute of Agrarian Economics"
}

The purpose. To study influence of degradation processes upon normative money evaluation, to carry out its recomputation at conditional exclusion of low-productive and degraded soils from plouhglands. Methods. Statistical-economic, abstractlogical, comparative analysis, calculated. Results. It is fixed that at conditional exclusion from plouhglands of the degraded and low-productive soils the normative money evaluation of ploughland is increased. Conclusions. Heightening indexes of normative money evaluation in conditions of exclusion of degraded and low-productive soils from plouhglands will have ecological and economic effects. It will promote augmentation of rental rate for ground shares, to receipt of taxes for land in local budgets.

Key words: degradation processes, low-productive soils, normative money evaluation, ploughing, ecological state, ploughlands, conditional exclusion, grading.

The intensive use of agricultural lands in the Poltava region has led to deterioration of their ecological status, reduction of soil fertility and the spread of degradation processes that cause damage to land resources, negatively affecting the qualitative characteristics of soils. Their development reduces the yield of crops and affects the indicators of the normative monetary valuation of arable land.

Analysis of recent research and publications.

The problems of protecting land from degradation processes, the development of sustainable land use on ecological bases are devoted to the works of D.I. Babmidri, D.S. Dobryaka, A.P. Kanasha, V.M. Krivova, V.V. Medvedeva, A.G. Martina , I.A. Rozumny, A.M. Tretyaka and others. However, the problem of the impact of soil degradation on indicators of normative monetary valuation of agricultural lands remains poorly researched.

The purpose of the research is to study the impact of degradation processes on normative monetary valuation and to carry out its recalculation for the conditional seizure of unproductive and degraded soils from the arable land on the example of Zinkivsky and Shishatsky districts of the Poltava region.

Research methods. Statistical-economic, abstract-logical, comparative analysis, estimated.

Research results. The Poltava region is located in the forest-steppe zone of the central part of Ukraine. In its soil cover, the largest areas are typical black chernozems and chernozems, which are characterized by high natural fertility due to the high content of humus. On average, the amount of humus in the layer $0-20 \mathrm{~cm}$ ranges from 3.3 to $4.2 \%$. At the same time, the soil cover is significantly exposed to water and wind erosion [1].According to the NSC "Institute of Soil Science and Agrochemistry named after. O. G. Sokolovsky ", there are about 517.7 thousand hectares of eroded lands in the region, including 420.3 thousand hectares of arable land $(23.8 \%$ of the total area of arable land), of which 369.3 thousand are subject to water erosion , in the wind - 51,0 thousand hectares. That is, on the one hand, fertile chernozem soils predominate in the soil, and on the other, soil degradation processes cover a significant part of the oblast's territory.

Intensive agricultural use of land, non-compliance with scientifically substantiated farming systems, and the introduction of insufficient organic and mineral fertilizers leads to a decrease in the fertility of soils. According to the State Geocadaster of Ukraine, agricultural development of the Poltava region is $79.5 \%$, and agricultural land cultivation is $81.9 \%$. Excessive cultivation affects the ecological condition of the territory, enhances soil erosion.

Degraded and unproductive soils in Ukraine, which are included in the arable land, occupy more than $19 \%$ of their area. Excluding ecological losses, their use causes annually losses per hectare, since production costs are not offset by the yields received [2].

So, let's say, in Canada, a unified land classification system has been developed for their suitability for agricultural use, which is based on identifying factors limiting the use of land [3]. 
Ukraine has developed a classification of soils, which is a system of their distribution into independent and at the same time interconnected groups for the established complex of the most significant properties for the ordering of information about their natural and agricultural production resources and rational use [4].

Effective measures for elimination of natural and anthropogenic land degradation are the removal of intensive agricultural use of degraded and unproductive soils. Adjusting the structure of agricultural lands in the direction of reducing their cultivation will reduce the intensity of erosion processes, significantly improve the water balance of the territory, reduce the cost of soil protection measures [5].

No less important is the implementation of reclamation measures aimed at improving the chemical and physical properties of soils, preserving and increasing their fertility and creating a balanced rational land structure. Remediation measures include the harvesting and afforestation, the implementation of which is regulated by the provisions of the Law of Ukraine "On land reclamation" (Articles 5, 8) [6].

In 1985 the Institute of Agriculture NAAS in cooperation with other scientific institutions, developed a contour-melioration organization of the territory, the implementation of which should ensure the protection of land from water and wind erosion, their rational use and protection, and optimize the structure of agricultural land. For the first time in Ukraine a systematic approach was found to solve the problem of the formation of environmentally sustainable agro-landscapes, prevention of water-borne processes, soil fertility, and improvement of the natural environment. Such a system of agriculture with the contour-land reclamation organization of the territory had to cover about 14 million hectares of agricultural land, but these works were not executed even in half of this area [7].

As a result of the land reform, a large part of degraded and unproductive lands was decomposed. Land acquisition was carried out on the basis of the normative monetary valuation of agricultural land, carried out in 1995 at all agrarian enterprises of Ukraine, and brought to the owners of land and land users. In the certificates issued to each member of the collective agricultural enterprise for the right to a land parcel (share), the value of the land parcel is indicated on the basis of the normative monetary valuation of the land of this enterprise.

The monetary assessment of agricultural land of all agricultural enterprises in Ukraine (evaluation of arable land, land under perennial plantations, hayfields, pastures) was carried out according to the method approved by the Cabinet of Ministers of Ukraine from March 23, 1995, No. 213, Procedure of monetary valuation of agricultural land and settlements, approved by the joint order of the State Committee of Ukraine for Land Resources of Ukraine, State Committee for Regional Development of Ukraine, Ministry of Agriculture of Ukraine and the Ukrainian Academy of Agrarian Sciences of 27 no Precipitation 1995 r. 76/230/325/150 number of changes, according to the order from 27.01.2006 № 18/15/21/11. By the Resolution of the Cabinet of Ministers of Ukraine No. 951 dated August 08, 2001, in the text of the methodology the word "in karbovanets" was replaced by the words " in hryvnias " [8, 9]. In the title and text of the method, the word "monetary assessment" is replaced by "normative monetary valuation" in accordance with the Resolution of the Cabinet of Ministers of Ukraine No. 843 of 05.07.2004 "On Amendments to certain Resolutions of the Cabinet of Ministers of Ukraine". The same decision changed the name of the methodology and removed the word "temporary". Now this document is called "Methodology of normative monetary valuation of agricultural land and settlements". Methodology The methodology is left unchanged.

The basis for determining the indicators of normative monetary valuation of agricultural land is the differential rental income that is created in the production of grain crops and is determined according to the economic assessment (these crops are grown on almost all soils, and they have the highest proportion in the structure of the crops).

The study on the correction of indicators of normative monetary valuation of arable land by conditional removal of degraded and unproductive soils was carried out on the example of Zinkivsky and Shishatsky administrative districts of the Poltava region, which belong to 06 and 07 land valuation areas (zoning was carried out during the economic evaluation of land).

From the scales of arable land evaluation for the efficiency of cultivating grain crops, indicators of differential rent income (the main criterion of estimation) are taken in the aspect of agro-industrial groups of soils [10].

In administrative districts, conditionally, from the arable land area with low differential income (and on some soils with negative), which, according to the classification of the suitability for cultivating crops, in particular cereals, are classified in classes IV and $\mathrm{V}$ (according to the scale of the suitability of the forest- 
steppe Left Bank province, which includes the investigated areas of the Poltava region) [2]. The area of such soils in Zinkivsky district is 3961 hectares, Shishatsky - 675 hectares. Predominantly, these are soils of light granulometric composition, poorly developed on the sands, regraded by strongly-swollen, saline, medium-and high-solonaceous, meadow-boggy, muddy-marsh, saline soils, peat-bogs (table 1).

1. Conditionally withdrawn degraded and unproductive soils of Zinkivsky and Shishatsky districts of the Poltava region

\begin{tabular}{|c|c|c|}
\hline Soils & $\begin{array}{l}\text { The code } \\
\text { of the soil }\end{array}$ & Proposed to use \\
\hline $\begin{array}{l}\text { Durn-Hidden-Ducts and Turf Low-Level } \\
\text { Soils on Tested Sands }\end{array}$ & 001 & $\begin{array}{l}\text { Unsuitable for use in arable land, belonging to } \\
\text { forestry. Selectively, you can use for pasture with } \\
\text { strictly normalized grazing }\end{array}$ \\
\hline $\begin{array}{l}\text { Deep-podzolic and turf non-glued and } \\
\text { glued soils on sandy sediments }\end{array}$ & $\begin{array}{l}005 \\
006\end{array}$ & $\begin{array}{l}\text { It is advisable to use it in field crop rotations. } \\
\text { Suitable for hummingbirds }\end{array}$ \\
\hline $\begin{array}{l}\text { Deep-podzolic gleyed saline soils, the } \\
\text { same as poorly washed soils }\end{array}$ & $\begin{array}{l}020 \\
021\end{array}$ & $\begin{array}{l}\text { As part of arable land you can use vegetable and } \\
\text { forage crops }\end{array}$ \\
\hline $\begin{array}{l}\text { The gray-gray and gray-pitted medium- } \\
\text { earth soils }\end{array}$ & 038 & $\begin{array}{l}\text { To use in soil protection crop rotation, steep sloping } \\
\text { areas - under pasture or permanent inclination }\end{array}$ \\
\hline $\begin{array}{l}\text { Dark gray podzolized and regraded } \\
\text { soils and chernozems are podzolovye } \\
\text { and regradovye strongly zmiti }\end{array}$ & 051 & $\begin{array}{l}\text { To be used for pastures or permanent feeding. } \\
\text { Blurred steep sloping areas - under forging }\end{array}$ \\
\hline $\begin{array}{l}\text { Chernozem typical and chernozems } \\
\text { strongly regressed strongly }\end{array}$ & 057 & $\begin{array}{l}\text { On slopes less than } 10^{\circ} \text {, the soils are suitable for } \\
\text { use in soil protection crop rotations. Hotbed blurred } \\
\text { - under the forest belt }\end{array}$ \\
\hline $\begin{array}{l}\text { Chernozems on the sands are unmixed } \\
\text { and weakened }\end{array}$ & 092 & $\begin{array}{l}\text { Suitable for use in perennials, in soil protection crop } \\
\text { rotation - under perennial grasses }\end{array}$ \\
\hline $\begin{array}{l}\text { Alpine, chernozem-meadow and } \\
\text { chestnut-meadow medium and high } \\
\text { salinity soils; the same in a complex } \\
\text { with solonets }\end{array}$ & $\begin{array}{l}135 \\
136\end{array}$ & $\begin{array}{l}\text { Use mainly as haymaking. Engaging in arable land } \\
\text { is possible subject to chemical reclamation }\end{array}$ \\
\hline $\begin{array}{l}\text { Moist-boggy, mud-muddy and peat- } \\
\text { marsh unpolluted soils }\end{array}$ & 141 & Requires special reclamation \\
\hline $\begin{array}{l}\text { Moist-boggy, mud-muddy and peat- } \\
\text { marsh unpolluted soils }\end{array}$ & 143 & $\begin{array}{l}\text { Unsuitable for agricultural use. Needed regeneration } \\
\text { (self-healing by natural way) }\end{array}$ \\
\hline $\begin{array}{l}\text { Salt mushrooms are shallow and } \\
\text { medium-deep salt marshes }\end{array}$ & 163 & Need chemical remodeling \\
\hline \multicolumn{3}{|c|}{$\begin{array}{l}\text { Source. According to the Institute "Ukrzemproekt" (now the Research and Design Institute of Land } \\
\text { Management). }\end{array}$} \\
\hline
\end{tabular}

After the conditional withdrawal of these soils in administrative regions, the main criterion for normative monetary valuation - differential rent income is listed.

According to the Order of the monetary assessment of agricultural land and settlements [9], the differential rental income of 1 hectare of arable land in the aspect of the administrative district is determined by the formula:

$\operatorname{Pdn}(p)=P d n(y) . P d(p): P d(y)$,

where Pdn $(p)$ - is the differential rental income of 1 hectare of arable land in the administrative district, c; Pdn (y) - differential rent income from 1 hectare of arable land in Ukraine, c; Pd (p) - differential rent income on the economic evaluation of the production of grain crops on arable land in the administrative region, UAH; $\mathrm{Pd}(\mathrm{y})$ - differential rent income on the economic evaluation of the production of grain crops on arable land, estimating these lands in Ukraine, UAH.

To the differential rent income from 1 hectare of arable land, determined by the formula, the absolute rent income is added (the constant value is defined in Ukraine for 1 hectare of land for the period of 1995 $-1,6 \mathrm{c})$, which is the total rent income (Pzdn). 
Normative monetary valuation of 1 hectare of arable land in an administrative district is determined by the formula:

Goz = Pzdn $\times$ Ц $\times$ Tk,

de Goz - normative monetary value of 1 hectare of arable land in administrative district, UAH;

Rzdn - total rent income on arable land in the administrative district, ts;

$Ц$ - the price of a centner of grain, UAH; Tk - the term of capitalization of rental income (in years), established at the level of 33 years (according to the current methodology).

After recalculation, the differential rental income from 1 hectare in Zinkivskyi district has increased by 32.2 UAH, Shishatsky - by $37.3 \mathrm{UAH}$ and is 447.4 and $465.8 \mathrm{UAH}$ respectively.

In tabl. 2 shows the calculation of normative monetary valuation of arable land by the new differential income.

2.Calculation of normative monetary value of 1 ha of arable land in Zinkivsky and Shishatsky districts

\begin{tabular}{|l|l|l|}
\hline \multirow{2}{*}{ Indexes } & \multicolumn{2}{|l|}{ Indicator value } \\
\cline { 2 - 3 } & Zinkivsky & Shishatsky \\
\hline $\begin{array}{l}\text { Differential rental income from 1 hectare of arable land by administrative } \\
\text { area (listed), UAH }\end{array}$ & & \\
\hline Differential rental income from 1 ha of arable land, c & 747,4 & 465,8 \\
\hline Differential rent income from 1 ha of arable land in Ukraine, UAH & 348,7 & 7,4 \\
\hline Differential rental income from 1 ha of arable land, c & 9,5 & 348,7 \\
\hline Absolute rental income & 1,6 & 1,6 \\
\hline Total rent income, c & 11,1 & 11,5 \\
\hline The term of capitalization, years & 33 & 33 \\
\hline Price 1 ts of grain, UAH & 12,5 & 12,5 \\
\hline Monetary valuation of 1 ha, UAH & 4579 & 4744 \\
\hline Source. Calculed by the auth
\end{tabular}

Source. Calculated by the authors in accordance with the Order of the normative monetary valuation of agricultural lands (annex 2, table 2.9)

After recalculation, the normative monetary value of 1 hectare of arable land in Zinkivsky district increased to $4579 \mathrm{UAH}$ (against $4396 \mathrm{UAH}$ in 1995), in Shishatsky rayon - up to $4744 \mathrm{UAH}$ (against 4411 $\mathrm{UAH}$ in 1995).

Since 2000, the monetary valuation of land plots as of January 1 is specified on the index of indexation, the procedure of which is approved by the Cabinet of Ministers of Ukraine in accordance with the Resolution of the Cabinet of Ministers of Ukraine dated May 12, 2000 No. 783 "On the indexation of monetary valuation of land".

From January 1, 2012, the Resolution of the Cabinet of Ministers of Ukraine of 31.10.2011 is in force, according to which the coefficient 1,756 is applied to indicators of normative monetary valuation of arable land (taking into account indexation).

According to the State Service of Ukraine for Geodesy, Cartography and Cadastre, the cumulative value of the indexation index of the normative monetary valuation of arable land as of 01.01.2016 (from $1995)$ is 4,796 .

Indicators of normative monetary valuation of 1 hectare of arable land according to the current methodology, taking into account indexation coefficients in Zinkivsky and Shishatsky districts, are 37022 and $37148 \mathrm{UAH}$, respectively.

On the basis of the calculations (for the conditional removal of degraded and unproductive soils), the monetary value of arable land in Zinkivsky and Shishatsky regions increased to 38563 and $39953 \mathrm{UAH}$, respectively.

\section{Conclusions}

Important directions for ensuring rational use and protection of land are the protection of soil from degradation, preservation and reproduction of its fertility, optimization of agricultural land use through the removal of intensive cultivation of unproductive and degraded land. 
Much of the strong and degraded lands need to be transformed into natural forage lands. In territories with the spread of wind erosion of the soil, it is necessary to carry out afforestation, to plant fieldprotecting forest strips, which will increase their ecological stability, will allow to increase the share of forests in the general land fund.

In the regulation of land relations an important role is played by the normative monetary valuation of agricultural land.

Improvement of normative monetary value of arable land in conditions of removal of degraded and unproductive soils from arable land will have ecological and economic effects. This will increase the rent for land parcels, the tax payments for land to local budgets.

\section{Bibliography}

1. Dovbish L.O. Low Productive and Degraded Land: problems and prospects /L.O. Dovbish //Newsletter of Poltava State Agrarian Academy. - 2010, No.3. - P. 165.

2. Classification of agricultural land as a scientific prerequisite for their environmentally safe use. - 2 nd form. papers / D.S. Dobriak, O.P. Kanash, D.I. Babmindra, IA Clever. - K.: Harvest. - 2009.- 464 p.

3. Canada Land Inventory. Rep. 2. Soil Capability Classification for Agriculture.- 1969. - 16 p.

4. Polupan M.I. Classification of soils of Ukraine /M.I. Polupan, V.B. Nightingale, VA Velichko; for ed. E. Hollow - K.: Agrar. science. - 2005. - 300 p.

5. Ecological problems of agriculture / I.D. Primak, Yu.P. Manko, N.M. Ridey et al .; for ed. I.D. Primak. - K.: Center for Educational Literature, 2010. - 456 p.

6. The Legal Institute for land reclamation in agriculture /O.O. Pogribny, L.O. Bondar, Bahay N.O. and others.//Agrarian Law of Ukraine, - K.: "Truth", 2007.- P.264.

7. Ovcharenko O.I. Major socio-economic and environmental impacts of land reform in agriculture /O.I. Ovcharenko //Land management. - 2001. - No.1. - P.20.

8. Resolution of the Cabinet of Ministers of Ukraine of March 23, 1995, No. 213 "On the Methodology of Monetary Evaluation of Agricultural Land and Human Settlements".//Handbook on reforming agricultural and processing enterprises; for ed. P.T. Sabluk, V.Ya. Mesel-Veselyak. - K.: IAE UAAS, 2000. - P. 308.

9. The order of normative monetary valuation of agricultural land and settlements //lbid. - P. 309.

10. Scale of arable estimation on the efficiency of cultivation of grain crops in the Poltava region. - K.: Institute "Ukrzemproekt", 1988. - 20 p. 